DIW BERLIN

Discussion

Papers
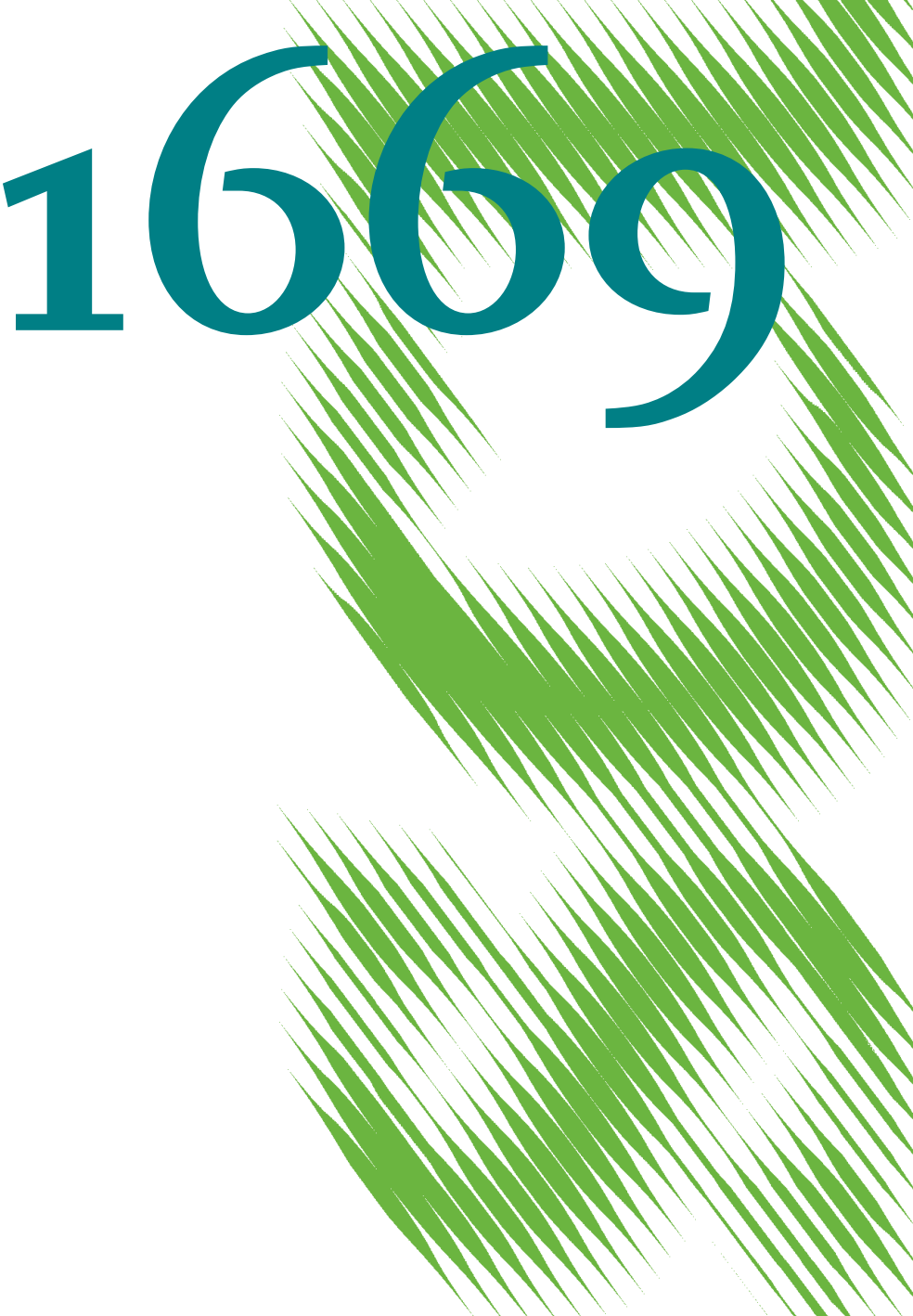

MMI

MMMMMMMMMMT

Stock Market Integration in Asia: Global or Regional?

Evidence from Industry Level Panel Convergence Tests 
Opinions expressed in this paper are those of the author(s) and do not necessarily reflect views of the institute.

IMPRESSUM

(C) DIW Berlin, 2017

DIW Berlin

German Institute for Economic Research

Mohrenstr. 58

10117 Berlin

Tel. +49 (30) $89789-0$

Fax +49 (30) $89789-200$

http://www.diw.de

ISSN electronic edition 1619-4535

Papers can be downloaded free of charge from the DIW Berlin website:

http://www.diw.de/discussionpapers

Discussion Papers of DIW Berlin are indexed in RePEc and SSRN:

http://ideas.repec.org/s/diw/diwwpp.html

http://www.ssrn.com/link/DIW-Berlin-German-Inst-Econ-Res.html 


\title{
Stock Market Integration in Asia: Global or Regional? Evidence from Industry Level Panel Convergence Tests
}

\author{
Guglielmo Maria Caporale \\ Brunel University London, CESifo Munich and DIW Berlin \\ Kefei You \\ University of Greenwich
}

May 2017

\begin{abstract}
This paper examines global and regional stock market integration in Asia at both the aggregate and disaggregate (industry) level by applying the Phillips-Sul (2007) tests for panel and club convergence. The main findings can be summarised as follows. In the pre-2008 crisis period, no integration/convergence of any kind is found. By contrast, in the post-crisis period, the Asian stock markets appear to be integrated both globally and regionally at the aggregate level; at the industry level, there is evidence of both global and regional integration in 6 out of 10 cases, the exceptions being Financials and Telecommunication, both in a turn-around phase, and Gas \& Oil and Technology, for which there is no panel convergence. Club convergence tests reveal the existence of convergence clubs and divergent economies within the full panel, which explains why panel convergence is not found for the pre-crisis period and for the Gas \& Oil and Technology sectors in the post-crisis period.
\end{abstract}

Keywords: Asian stock markets, global and regional integration, Phillips-Sul tests, panel and club convergence

JEL classification: $\mathrm{C} 32, \mathrm{C} 33, \mathrm{G} 11, \mathrm{G} 15$

Corresponding author: Professor Guglielmo Maria Caporale, Research Professor at DIW Berlin. Department of Economics and Finance, Brunel University London, Kingston Lane, Uxbridge UB8 3PH, United Kingdom. Tel.: +44 (0)1895 266713. Fax: +44 (0)1895 269770. Email: Guglielmo.Maria.Caporale@brunel.ac.uk 



\section{Introduction}

Cross-border financial integration is generally thought to bring benefits to an economy by lowering the costs of asset trading and offering more portfolio diversification opportunities. For these reasons many Asian countries, especially after the 1997 crisis, embarked upon financial deregulation programmes with the aim of removing the inefficiencies caused by the previous restrictions on capital flows and achieving welfare gains. Indeed, in the last couple of decades cross-border financial flows have increased significantly in most Asian economies (see Park, 2013). However, the benefits have not been as large as anticipated, possibly because integration has been incomplete, and also because higher openness has made these economies more vulnerable to contagion during periods of financial turmoil such as the recent global crisis. Analysing their degree of integration and its patterns is therefore crucial also from a policy perspective, since different policy measures aimed at achieving financial stability might be required in response to exogenous shocks depending on the nature of the linkages between these financial markets. In particular, regional financial integration might be an appealing alternative to globalised finance with its associated contagion risks: since the Asian region as a whole runs a large current account surplus, which means that regional saving exceeds regional investment, higher regional integration might be preferable to riskier global exposure to address the borrowing needs of individual Asian countries (see Devereux et al., 2011).

There is in fact some evidence that regional financial integration has been the main funding source for domestic investment, Japanese saving in particular financing a sizeable percentage of investment in the region (see Kim et al., 2011). Regional initiatives boosting intraregional trade have also stimulated financial integration as shown by changes in the composition of portfolio equity holdings (see Lane, 2011). Bae (2011) provides evidence of a higher degree of both global and regional integration of the Asian stock markets using principal component analysis. Hinojales and Park (2011) estimate conditional correlations also for stock returns at the disaggregate, industry level data and find that financial integration with the rest of the world is greater than within the region.

Park (2013) addresses similar issues by measuring both $\beta$ - and $\sigma$-convergence (see Barro and Sala-i-Martin, 1991, 1992) in emerging Asia and some sub-groupings. 
She finds that the cross-market dispersion of weekly stock market returns has declined and returns have converged over time; as for bond markets, the sovereign debt problems experienced by some Asian countries combined with the global financial crisis has resulted in a lower degree of convergence. She also uses principal component analysis to model returns as having both expected and unexpected components, the latter including local, regional and global shocks. The evidence she obtains suggests that the Asian stock markets have become more integrated at the global than the regional level, whilst both types of integration have declined in the case of bond markets.

The present paper also examines stock market integration in Asia, more specifically whether the Asian markets are more integrated with global or regional markets (the US being used as an indicator of the former, and Japan and the rest of Asia as two alternative indicators of the latter). Our contribution is three-fold. First, the analysis is carried out using return differentials at both the aggregate and industry level, the latter providing evidence on which industries drive Asian financial integration. Very few previous studies have analysed industry level data to compare global to regional integration. In particular, Hinojales and Park (2011) estimate a DCC model using weekly data for the period 1993-2009, whilst we employ a panel convergence method and also cover a longer period, until 2016.

Second, we examine whether the degree and pattern of integration has been affected by the 2008 global financial crisis by splitting the sample and comparing the pre- and post-crisis periods. This is again an issue not thoroughly investigated in the existing literature. Wu et al. (2015) and Wang (2014) both use daily data at the aggregate level. The former focus on the transmission of shocks (contagion) from the US, Japan, and Hong Kong to other Asian countries and hence integration among East Asia stock market themselves is not explained. Compared with the latter, our study adopts alternative measures of financial integration as well as a different empirical method, and provides further evidence at the industry level.

Third, we apply the Phillips and Sul (2007) tests for both panel and club convergence, which are ideally suited to test for global and regional integration in the Asian stock markets. To our knowledge, these tests have only been used in two previous studies on Asia, namely those by Apergis et al. (2014) and Tam and Tam (2012) for a panel of over 40 countries. However, neither paper analyses global versus regional integration (returns are used instead of return differentials), the former only 
covers the period up to 2008, and the latter does not consider either the impact of the recent global financial crisis or club convergence (it uses stock valuation ratios such as earnings-, dividend-, and book-price ratios for the analysis).

Our main findings can be summarised as follows. In the pre-crisis period, no integration/convergence at either the global or regional level is found for the Asian stock markets; this is true for both aggregate and industry level stock returns. By contrast, in the post-crisis period, the Asian markets appear to be integrated both globally and regionally at the aggregate level; at the industry level, there is evidence of both global and regional integration in 6 out of 10 cases, the exceptions being Financials and Telecommunication, both in a turn-around phase, and Gas \& Oil and Technology, for which there is no panel convergence. Club convergence tests reveal the existence of convergence clubs and divergent economies within the full panel, which explains why panel convergence is not found for the pre-crisis period and for Gas \& Oil and Technology sectors in the post-crisis period.

The layout of the paper is as follows. Section 2 reviews the relevant literature. Section 3 outlines the empirical method used for the analysis, namely the Phillips and Sul (2007) convergence tests. Section 4 describes the data and discusses the empirical findings. Section 5 offers some concluding remarks and highlights the policy implications of the analysis.

\section{Literature Review}

There are three main types of measures of financial integration in the existing literature, based on prices, volume and regulatory or institutional factors respectively. The first is often embodied in interest parities conditions in the money markets or in co-movements in assets returns in stock and bond markets. Studies employing volume-based measures often examine the saving-investment correlations pioneered by Feldstein and Horioka (1980), consumption correlations (e.g., Bayoumi, 1997; de Browuer, 1999) and capital flows (cross-border financial transactions) (e.g., Cavoli et. al., 2006). The third type is often based on the presence or not of capital controls and legal restrictions such as those on foreign equity holdings (e.g., Grilli and MilesiFerretti, 1995; Magud and Reinhart, 2006).

Price-based measures have been most often employed to analyse Asian stock market integration. Both (time-varying) correlations and VAR (cointegration) models with impulse response analysis have been used in various papers (see Sharma and 
Seth, 2012). ${ }^{1}$ Some recent correlation studies include Loh (2013) (applying the wavelet coherence method), Abid et al. (2014) (using the multivariate General Dynamic Covariance (GDC)-GARCH model), Boubakri and Guillaumin (2015), Narayah et al. (2014) (both using GARCH-dynamic conditional correlations (DCCs)), Dewandaru et al. (2015) (using wavelet decomposition techniques), Cao et al. (2017) (using volatility constrained multi-sfractal de-trended cross-correlation analysis (VCMF-DCCA)) and Wang et al. (2017) (using the coupling de-trended fluctuation analysis (CDFA) method).

Examples of VAR studies are Huyghebaert and Wang (2010) and Wang (2014) that examine both long- and short-term linkages using cointegration tests and impulse response analysis respectively. Gupta and Guidi (2012) and Chien et al. (2015) focus on India and China respectively within a cointegration framework.

Most of the available evidence suggests increasing financial integration between the Asian stock markets; however, it appears that global is stronger than regional integration (e.g., Hinojales and Park, 2011; Park and Lee, 2011; Kim et al., 2011; Kim and Lee, 2012). As already mentioned, some recent studies have measured both $\beta$ - and $\sigma$-convergence in Asia and found convergence of stock markets and divergence of bond markets (Park, 2013).

\section{The Methodology}

Barro and Sala-i-Martin $(1991,1992)$ introduced the concepts of $\beta$ - and $\sigma$ convergence, the former implying mean reversion for the panel units, whilst the latter is a reduction in overall cross-section dispersion. Islam (2003) highlighted some problems with standard convergence tests (see also Durlauf and Quah, 1999 and Bernard and Durlauf, 1996): the implications of growth models for absolute convergence and convergence "clubs" are not clear; different tests do not have the same null hypothesis and therefore are not directly comparable; most tests are based on rather specific and restrictive assumptions about the underlying panel structures.

A new non-linear, time-varying coefficient factor model without such limitations has been developed by Phillips and Sul (2007), who proposed a regression-based test together with a clustering procedure. Their approach is not dependent on stationarity assumptions and allows for a wide variety of possible transition paths toward

\footnotetext{
${ }^{1}$ For a review of the literature on financial integration in Asia focusing on money and bond markets, see Rughoo and You (2016).
} 
convergence (including sub-group convergence). Specifically, it is based on a timevarying factor model using common stochastic trends, which can accommodate longterm co-movement in aggregate behaviour outside the cointegration framework and allows for the modelling of transitional effects. Being based on such a time-varying factor model, the Phillips and Sul (2007) method is more powerful than the traditional $\beta$ - and $\sigma$-convergence tests, and it provides estimates of the speed of convergence for both the full panel and sub-groups through its club formation procedure. This method is explained in detail below.

\subsection{Relative Transition}

Phillips and Sul (2007) (P-S) proposed the new time-varying loading factor representation for the panel variable $X_{i t}$ :

$$
X_{i t}=\delta_{i t} \mu_{t},
$$

where $\mu_{t}$ is a single common component and $\delta_{i t}$ is a time-varying factor-loading coefficient that measures the idiosyncratic distance between the common trend components $\mu_{t}$ and $X_{i t}$.

To obtain information about the time-varying factor loading $\delta_{i t}$, Phillips and Sul (2007) employed the relative version of $\delta_{i t}$, the relative loading factor or the relative transition parameter, as follows:

$$
h_{i t}=\frac{X_{i t}}{\frac{1}{N} \sum_{i=1}^{N} X_{i t}}=\frac{\delta_{i t}}{\frac{1}{N} \sum_{i=1}^{N} \delta_{i t}},
$$

where $h_{i t}$ is the relative transition parameter that measures $\delta_{i t}$ in relation to the panel average at time $t$ and therefore describes the transition path for country or area $i$ relative to the panel average. If $\delta_{i t}$ converge to $\delta$, then the relative transition parameters $h_{i t}$ converge to unity. In this case, the cross-sectional variance of $h_{i t}$, $H_{t}$, converges to zero in the long run:

$$
H_{t}=\frac{1}{N} \sum_{i=1}^{N}\left(h_{i t}-1\right)^{2} \rightarrow 0 \text { as } t \rightarrow \infty .
$$

\subsection{The $\log t$ Convergence Test}

P-S proposed a simple regression-based testing procedure to examine the null of convergence, $H_{0}: \delta_{i}=\delta$ and $\alpha \geq 0$, against the alternative of $H_{A}: \delta_{i} \neq \delta$ or $\alpha<0$. The procedure involves three steps. First, the cross-sectional variance ratio $H_{1} / H_{t}$ is calculated, given that $H_{t}=\frac{1}{N} \sum_{i=1}^{N}\left(h_{i t}-1\right)^{2}$. Second, the following ordinary least 
squares regression is run, and a conventional robust $t$ statistics, $t_{\hat{b}}$, is calculated for the coefficient $\hat{b}$ using the estimate of the long-run variance of the regression residuals:

$$
\log \left(\frac{H_{1}}{H_{t}}\right)-2 \log L(t)=\hat{a}+\hat{b} \log t+\hat{u}_{t}
$$

for $t=[r T],[r T]+1, \ldots, T$ with some $r>0$. P-S recommended $r=0.3$ on the basis of their simulations. Other settings of the regression include $L(t)=\log (t+1)$ and the fitted coefficient of $\log t$ is $\hat{b}=2 \hat{a}$, where $\hat{a}$ is the estimate of $a$ under the null. A one-sided $t$ test of null $\alpha \geq 0$ using $\hat{b}$ is then performed and the null of convergence is rejected at a $5 \%$ significance level if $t_{\hat{b}}<-1.65$.

Note that $\hat{\alpha} \geq 1$ and, accordingly, $\hat{b} \geq 2$ implies level (i.e., absolute) convergence and that $1>\hat{\alpha} \geq 0$ and therefore $2>\hat{b} \geq 0$ implies rate (i.e., conditional) convergence.

\subsection{Club Convergence and Clustering}

Rejection of the null of full-panel convergence does not imply that there is no convergence. There may be one or more convergent clusters as well as divergent units in the panel. P-S provided a four-step algorithm to detect such units of clusters that is based on repeated $\log t$ regressions and involves the following steps:

(i) Order the panel units $X_{i t}$ according to the last observation, $X_{i T}$.

(ii) Select the first $k$ highest panel units $(N>k \geq 2)$ and calculate $t_{\hat{b}}(k)$ for each $k$. The core group size $k^{*}$ is chosen according to $k^{*}=\operatorname{argmax}_{k}\left\{t_{\hat{b}}(k)\right\}$ subject to $\min \left\{t_{\hat{b}}(k)\right\}>-1.65$. If $k^{*}=N$, there is full-panel convergence. If $\min \left\{t_{\hat{b}}(k)\right\}>-1.65$ does not hold for $k=2$, drop the first unit and perform the same procedure for the remaining units. If $\min \left\{t_{\hat{b}}(k)\right\}>-1.65$ does not hold for every subsequent pair of units, there are no convergent clusters in the panel.

(iii) Add one remaining unit at a time to the core group and perform the $\log t$ test. If the corresponding $t$ statistic from this regression, $\hat{t}$, exceeds a chosen critical value, $c^{2}$, then include the unit in the current subgroup. The $\log t$ test is run for this sub-group, and if $t_{\widehat{b}}>-1.65$, the formation of the sub-group is completed. Otherwise, increase the critical value $c$ and repeat the procedure.

\footnotetext{
${ }^{2}$ Note that, following Phillips and Sul (2009), we set $c=0$, as the number of observation is not particularly large.
} 
(iv) A subgroup of the units is formed for which $\hat{t}<c$ in (iii). Run the $\log t$ test for this subgroup, and if $t_{\hat{b}}>-1.65$, this cluster converges, and there are two convergent sub-groups in the panel. Otherwise, repeat (i)-(iii) on this sub-group to determine whether a smaller convergent sub-group exists. If there is no $k$ in (ii) for which $t_{\widehat{b}}(k)>-1.65$, the remaining units diverge.

The Phillips and Sul (2007) method has been employed for a range of developed stock markets. For instance, Caporale et al. (2015) apply it to test for convergence in the stock returns of five EU countries (Germany, France, the Netherlands, Ireland and the UK) as well as the US between 1973 and 2008, for both sectors and individual industries within sectors. Concerning studies focusing on Asia, as already mentioned the only two previous applications are Apergis et al. (2012) and Tam and Tam (2012).

\section{Empirical Analysis}

\subsection{Data}

The Asian economies included in this study are China (PRC), Hong Kong, India, Indonesia, Malaysia, Pakistan, Philippines, Singapore, South Korea, Sri Lanka, Taiwan, and Thailand. The data source is Datastream. Stock market returns are calculated as monthly log first differences. Then three sets of return differentials are constructed vis-à-vis 1) the US; 2) Japan; and 3) Asia (excluding Japan).

We employ data at both the aggregate and industry level. The following ten sectors are included in the analysis: 1) Basic Materials, 2) Consumer Goods, 3) Consumer Services, 4) Financials, 5) Healthcare, 6) Industrials, 7) Oil \& Gas, 8) Technology, 9) Telecommunications, and 10) Utilities. The frequency is monthly and the sample period is 2000M1-2016M9. To investigate the impact of the 2008 financial crisis we divide the full sample into two sub-periods, namely 2000M1-2007M12 and 2009M1-2016M9, excluding the two-year period 2007M10-2009M9 that is characterised by extreme volatility.

\subsection{Logt Test Results}

Following Phillips and Sul's (2007) recommendation, we apply the Hodrick and Prescott (1997) filter to remove the cycle component of each series before running the convergence test on the return differentials. The first step is to examine full-panel 
convergence applying the logt test. The test results are displayed in Table 1. At the aggregate level, the null of convergence is rejected at the $5 \%$ level in the pre-crisis period in all three cases, suggesting absence of both global and regional integration. However, in the post-crisis period there is conditional convergence (convergence in rates) (given that $2>\hat{b} \geq 0$ ) in the return differentials at both the global and regional level, and the speed of convergence for the three sets of differentials is very similar (i.e., above 0.5 and below 0.6).

Moving on to the sector level results, in the pre-crisis period panel convergence is rejected in all three cases (i.e., relative to the US, Japan, and Asia (excluding Japan)) for all ten sectors, which suggests that the absence of convergence at the aggregate level in the pre-crisis period reflects lack of convergence at the sector level. By contrast, in the post-crisis period returns differentials in six out of ten sectors exhibit conditional convergence (since $2>\hat{b} \geq 0$ ), again at a very similar speed for all sets of differentials. The four exceptions are Financials, Telecommunication, Oil \& Gas, and Technology. It is noteworthy that in the case of the former two sectors the point estimates are negative and not significantly different from zero; following Phillips and Sul (2009), this indicates that the Financials and Telecommunication sectors are in transitional divergence and in a turn-around phase, with convergence occurring in the post-crisis period. For Oil \& Gas and Technology convergence is rejected and hence there is no evidence of integration regardless of the period or level of integration (global or regional) considered.

Therefore, it appears that there is both global and regional integration at the aggregate level in the post-crisis period. At the sector level there is evidence of both global and regional integration, except for Oil \& Gas, Technology (full panel convergence is rejected) and Financials and Telecommunication sector (that are in transitional divergence and turn-around phase). There is slightly stronger evidence of global than regional integration at both the aggregate and sector level (except for the sectors mentioned before), since the speed of convergence, $b$, is consistently higher (though by a small amount) in the former case.

\subsection{Club Convergence Results}

As argued by Phillips and Sul (2007), a rejection of full-panel convergence on the basis of the logt test does not rule out the possibility of club convergence and the 
presence of divergent members. Hence our next step is to apply the P-S clustering algorithm to the panel and identify those.

Since we are more interested in the recent post-crisis period, we first carry out club convergence analysis for the Oil \& Gas and Technology Sectors, the only two sectors where full-panel convergence is rejected in the post-crisis period. The results are presented in Table 2. Since full-panel convergence is rejected at both the aggregate and sector level in the pre-crisis period, we also carry out club convergence tests for this sub-sample to establish whether this rejection is due to the presence of convergence clubs and/or divergent economies. The results are presented in Table 3.

\section{Oil and Gas Sector}

For this sector, in the case of return differentials vis-à-vis the US, one convergence club is identified including China, India, Hong Kong, Malaysia, Philippine, Thailand, Pakistan, and Sri Lanka. Singapore and South Korea are two divergent countries that neither belong to the convergence club nor converge between themselves. As for the return differentials vis-à-vis Japan and Asia (excluding Japan), only Singapore diverges and all the other countries belong to a convergence club. It is worth mentioning that the convergence club based on the return differentials vis-à-vis the US is converging at a faster speed (i.e., a higher value of $\hat{b}$ ) than that based on the differentials vis-à-vis Japan and Asia. Therefore, rejection of full-panel convergence in the post-crisis period is due to Singapore and South Korean diverging in the case of the return differentials vis-à-vis the US, and Singapore diverging in the case of the differentials vis-à-vis Asia.

Figures 1-3 present the corresponding relative transition parameters for the Oil \& Gas sector in all ten countries. Figure 1 highlights the fact that Singapore and South Korea have diverged from the other economies, especially towards the end of the post-crisis period. Figures 2 and 3 show the divergence of Singapore with much lower relative transition parameters towards the end of our sample period. In the case of South Korea, although its relative transition parameters are also higher than for other economies since 2015, the overall transition path is more similar to theirs than in Figure 1, which suggests that this country, unlike Singapore, belongs to the convergence club. 
Table 3 reports the club convergence tests for the Oil \& Gas sector in the precrisis period. On the basis of the return differentials vis-à-vis the US, three clubs can be identified, with clubs 1 and 3 being in transitional divergence and a turn-around

phase, and club 2 having conditional convergence given by $2>\hat{b} \geq 0$. The same three clubs can also be identified in the case of the return differentials vis-à-vis Japan and Asia, although only club 3 (Pakistan and Sri Lanka) is in a transitional phase while the economies in club 1 (China, Hong Kong, Thailand and South Korea) converge at a relatively faster speed than those in club 2. Therefore, the rejection of full-panel convergence in the pre-crisis period is due to the presence of some convergence clubs as well as some transitional clubs.

A comparison of the two sub-periods shows that, for the Oil \& Gas Sector, both global and regional integration are stronger in post- than in pre-crisis period as most economies (with one or two exceptions) have experienced club convergence. There is slightly stronger evidence of regional integration (based on a faster speed of convergence and the existence of only one club in a transitional phase) in the precrisis period and of global integration (given a slightly faster speed of convergence) in the post-crisis period. This suggests that the Asian energy markets, despite being more globally and regionally integrated after 2008, have been more influenced by the global markets after the crisis.

\section{Technology Sector}

In the post-crisis period, two clubs can be identified, with Hong Kong and Taiwan in club 1 and China, India, Singapore, Thailand and South Korea in club 2. This is the case for all three sets of differentials, although the speed of convergence (measured by the value of b) is slightly higher in the case of the differentials vis-à-vis Japan and Asia. Therefore, rejection of full-panel convergence in the post-crisis period is due to the existence of two separate convergence clubs. Further, their speed of convergence suggests that regional integration is slightly stronger than the global one.

Figures 4-6 present the relative transition parameters for all seven countries in the Technology sector. In all cases Hong Kong and Taiwan have transition curves that are moving together and upwards faster than those of the other economies towards the end of the sample period, suggesting higher differentials vis-à-vis the US, Japan and Asia than for other emerging Asian economies since 2015. 
Table 3 reports club convergence test for the Technology sector in the precrisis period. There is one club where economies are in a transitional phase and one divergent country, i.e. China, for all three sets of differentials. Therefore, rejection of full-panel convergence in the pre-crisis period is due to China diverging and the other countries being in a transitional divergence and turn-around phase.

Although full-panel convergence is rejected for both pre- and post-crisis periods, there are signs of both global and regional integration in the latter period since two convergence clubs can be found, compared with no convergence clubs in the former. The divergence of China in the pre-crisis period and its belonging to one of the convergence clubs in the post-crisis period suggest that the Technology sector of this country has become regionally and globally integrated. Hong Kong and Taiwan form a convergence club in the post-crisis period, confirming their leading positions in this sector in Asia. The speed of convergence for the clubs is slightly faster at the regional level, which again indicates stronger regional integration within clubs in the post-crisis period.

\section{Aggregate and other sector results in the pre-crisis period}

Since full-panel convergence is rejected in all cases in the pre-crisis period, we now analyse the club convergence test results in Table 3 to establish whether this is due to the existence of convergence clubs and/or divergent economies.

At the aggregate level, there is one convergence club including India, Hong Kong, Indonesia, Malaysia, Philippine, Singapore, South Korea, Taiwan, Pakistan, and Sri Lanka, whilst China and Thailand form one transitional club. This is the case regardless of the differentials used. Therefore, the lack of full-panel convergence in the pre-crisis period at the aggregate level is mainly due to the fact that China and Thailand are in a transitional divergence and turn-around phase.

As for the sector level data, we first consider the Financials sector. Prior to the crisis, three convergence clubs and one transitional club can be identified in the case of the differentials vis-à-vis the US, whilst on the basis of those vis-à-vis Japan and Asia there are two convergence clubs. Although all three sets of differentials suggest that there are economies in a transitional phase in the post-crisis period, there is stronger evidence of regional integration prior to the crisis since only a few clubs can be identified when considering the differentials vis-à-vis Japan and Asia. 
Concerning the Telecommunication sector, two convergence clubs are found for all three sets of differentials, although Singapore and Pakistan belong to club 1 in the case of the differentials vis-à-vis the US and Japan and instead to club 2 in the case of those vis-à-vis Asia. Hence there are two convergence clubs in the pre-crisis period and a transitional club in the post-crisis period.

Regarding the other six sectors, our results reveal that there are three convergence clubs for Basic Materials, two convergence clubs and one transitional club for Consumer Goods, two convergence clubs for the Utility sector, one convergence and one transitional club for the Industrial sector, one convergence club and two divergent economies (China and Taiwan) for the Consumer Services sector, and one convergence club, one transitional club, and two divergent countries (India and Philippine) for Healthcare. When convergence clubs are found, there is conditional convergence $(2>\hat{b} \geq 0)$ except in the case of Healthcare and Consumer Goods in club 3 when level convergence $(\hat{b} \geq 2)$ is found. This holds regardless of what type of differentials are used for the analysis.

Both at the aggregate and sector level, prior to the crisis, global and regional integration is only found for some sub-groups. The degree of global and regional integration are very similar in terms of their speed of convergence and convergence clubs, transitional clubs, and divergent economies across the three data set. There are only two exceptions. The first is the Financials sector where slightly stronger evidence of regional integration is detected given the smaller number of clubs. The second is the Oil \& Gas sector where stronger evidence of regional integration is found since there are fewer transitional clubs and a faster speed of club convergence. It is also noteworthy that China has moved from often diverging or being in a transitional club in the pre-crisis period to becoming a member of a convergence club in the second sub-period, which suggests that it has become more integrated, both globally and regionally, after the crisis.

\section{Conclusions}

This paper investigates whether the Asian stock markets are more integrated at the global or regional level (the US being used as an indicator of the former, and Japan and the rest of Asia as two alternative indicators of the latter). We analyse return differentials at both the aggregate and industry level, the latter shedding light on 
which sectors drive integration. Specifically we carry out the Phillips-Sul (2007) tests for panel and club convergence, which are more powerful than conventional $\beta$ - and $\sigma$ convergence tests, paying special attention to contrasting convergence patterns between the pre- and post-crisis periods.

We find that in the pre-crisis period there is no integration/convergence at either the global or regional level for the Asian stock markets, regardless of whether one uses aggregate or industry level stock returns. By contrast, in the post-crisis period, the Asian markets appear to be integrated both globally and regionally at the aggregate level. Further tests using the industry level data show that there are 6 out of 10 industries driving integration, the exceptions being Financials and Telecommunication, both in a turn-around phase, and Gas \& Oil and Technology, for which there is no panel convergence. Is it also noteworthy that where full-panel convergence is found, at both the aggregate and industry level, global integration is slightly stronger than regional integration (judged by the speed of convergence).

Further club convergence tests for the Gas \& Oil and Technology sectors in the post-crisis period reveal the existence of convergence clubs and divergent economies, which explains the lack of full-panel convergence for these two industries. The evidence on the convergence clubs suggests that the energy sector is more influenced by the global than the regional markets after the 2008 global financial crisis, while the opposite is true for the Technology sector. In addition, we also find that the absence of full-panel convergence in the pre-crisis period is due to the existence of a transitional club (formed by China and Thailand) at the aggregate level and of convergence/transitional clubs and/or divergent economies at the industry level.

Of the countries examined China, often found to be in a transitional club or to be a divergent economy, has become far more globally and regionally integrated after the 2008 global financial crisis. The speed of convergence for both sets of regional stock return differentials implies that, when either full-panel or club convergence occurs, in most cases the Asian stock markets are more integrated with Japan than with the regional index. Therefore Japan appears to be a regional leader and continues in fact to be the main source of funding for investment in the region (see Kim et al., 2011).

Whilst several previous studies provide more evidence of global integration (e.g., Hinojales and Park, 2011; Park and Lee, 2011; Kim et al., 2011; Kim and Lee, 
2012; Park, 2013), ours finds very similar levels of global and regional integration at both the aggregate and industry level, the former being only slightly stronger. Therefore, although various regional agreements such as the Chiang Mai Initiative in 2000, the Asian Bond Market Initiative (ABMI) in 2003, the new ABMI roadmap in 2008 and the Chiang Mai Initiative Multilateralization in 2012 have been signed to enhance regional cooperation, this should be promoted further to achieve a level of integration similar to that with the US.

Further, the 2008 global financial crisis appears to have resulted in tighter global and regional financial integration in the case of Asia, possibly because it provided stronger incentives for (regional) integration to deal with external common shocks (Asian Development Bank, 2013). This finding goes contrary to previous claims of a decoupling between Asia and the US (e.g., Leduc and Spiegel, 2013). Such stronger financial linkages require that an appropriate policy framework be in place to deal with future crises. In particular, since the recent global financial crisis originating from the US affected emerging equity markets primarily through a decline in investor's risk appetite (Chudik and Fratzscher, 2011), measures such as the daily one proposed by Kumar and Persaud (2002) should be used to keep track of it. Moreover, risk sharing between the Asian countries should be increased; as suggested by Ding et al. (2014), greater financial inclusion and innovation would contribute to achieve this objective and make the Asian economies more resilient in the presence of external shocks.

Finally, our findings have implications for investors seeking portfolio diversification, since the four sectors that do not appear to be tightly integrated across countries offer investment opportunities for both global and regional diversification. However, this is not the case for either China or Japan given the evidence of strong integration of their stock markets. 


\section{References}

Abid, I., Kaabia, O. and Guesmi, K., 2014, Stock market integration and risk premium: Empirical evidence for emerging economies of South Asia, Economic Modelling 37, 408-416

Apergis, N., Christou, C. and Miller S. M., 2014, Country and industry convergence of equity markets: International evidence from club convergence and clustering, The North American Journal of Economics and Finance, 29, 36-58.

Asian Development Bank (2013, October). Regional cooperation and integration. In Asian Development Bank (Ed.), Asian Economic Integration Monitor. Asian Development Bank.

Bae, K.-H. (2011), “Stock market integration and financial contagion”, in Devereux, M.B., Lane, P.R., Park, C.-Y. and S.-J. Wei (eds.), The Dynamics of Asian Financial Integration - Facts and Analytics”, 135-173, Routledge, Abingdon, UK.

Barro, R. J., X. Sala-i-Martin (1991), Convergence across States and Regions, Brookings Papers on Economic Activity, 22, 107-182.

Barro, R. J., X. Sala-i-Martin (1992), Convergence, The Journal of Political Economy, 100, 2, 223-251.

Bayoumi, T. (1997). Financial integration and real activity. Manchester University Press.

Bernard, A., S. N. Durlauf (1996), Interpreting Tests of the Convergence Hypothesis, Journal of Econometrics, 71, 1-2, 161-173.

Boubakri, S. and Guillaumin, C., 2015, Regional integration of the East Asian stock markets: An empirical assessment, Journal of International Money and Finance 57, 136-160

Cao, G., Zhang, M. and Li, Q. (2017), Volatility-constrained multifractal detrendedcross correlation analysis: Cross-correlation among Mainland China, US, and Hong Kong stock markets, Physica A 472, 67-76.

Caporale, G.M., Erdogan, B. and V. Kuzin (2015), Testing for convergence in stock markets: a non-linear factor approach, Empirica, 42, 3, 481-498.

Cavoli, T., Rajanb, R.S. and Siregarc, R. (2006). Financial integration in East Asia: How far? How much further to go? eSocialSciences Working Papers, 372.

Chien, M.-S., Lee, C-C., Hu, T-C. and Hu, H-T. (2015), Dynamic Asian stock market convergence: Evidence from dynamic cointegration analysis among China and ASEAN-5 Economic Modelling 51, 84-98.

Chudik, A., Fratzscher, M. (2011). Identifying the global transmission of the 20072009 financial crisis in a GVAR model. European Economic Review 55 (3), 325-339. 
deBrowuer, G. (1999). Financial integration in East Asia. Cambridge University Press.

Devereux, M.B., Lane, P.R., Park, C.-Y. and S.-J. Wei (2011), "Executive summary and overview”, in Devereux, M.B., Lane, P.R., Park, C.-Y. and S.-J. Wei (eds.), The Dynamics of Asian Financial Integration - Facts and Analytics", 1-18, Routledge, Abingdon, UK.

Dewandaru, G., Masih, R. and Masih, A.M.M., 2015, Why is no financial crisis a dress rehearsal for the next? Exploring contagious heterogeneities across major Asian stock markets, Physica A 419, 241-259

Durlauf, S. N., D. T. Quah (1999), The New Empirics of Economic Growth, in Taylor J. B., M. Woodford (eds.), Handbook of Macroeconomics, vol. 1, chapter 4, 235-308.

Ding, D., Peiris, S. J. and Lam, W. R., 2014, Future of Asia’s Finance: How Can it Meet Challenges of Demographic Change and Infrastructure Needs? IMF Working Paper WP/14/126.

Feldstein, M., and Horioka, C. (1980). Domestic saving and international capital flows. Economic Journal 90, 314-329.

Grilli, V., and Milesi-Ferretti, G.M. (1995). Economic effects and structural determinants of capital controls. IMF Staff Papers, 42, 517-551.

Gupta, R., and Guidi, F. (2012), Cointegration relationship and time varying co movements among Indian and Asian developed stock markets, International Review of Financial Analysis 21, 10-22.

Hinolajes, M. and C.-Y. Park (2011), "Stock market integration: emerging East Asia' experience”, in Devereux, M.B., Lane, P.R., Park, C.-Y. and S.-J. Wei (eds.), The Dynamics of Asian Financial Integration - Facts and Analytics”, 174-203, Routledge, Abingdon, UK.

Huyghebaert, N. and Wang, L., 2010, The co-movement of stock markets in East Asia Did the 1997-1998 Asian financial crisis really strengthen stock market integration? China Economic Review 21, 98-112.

Islam, N. (2003), What have We Learnt from the Convergence Debate?, Journal of Economic Surveys, 17, 3, 309-362.

Kim, S., Kim S. H. and C.-Y. Park (2011), International capital mobility of East Asian economies: is domestic investment financed by regional or global saving?, in Devereux, M.B., Lane, P.R., Park, C.-Y. and S.-J. Wei (eds.), The Dynamics of Asian Financial Integration - Facts and Analytics”, 52-76, Routledge, Abingdon, UK.

Kim, S. and Lee, J. -W. (2012). Real and financial integration, real and financial integration in east Asia. Review of International Economics 20(2), 332-349. 
Kim, S, Lee, J. -W. and Park C.- Y., 2011, Emerging Asia: Decoupling or Recoupling, The World Economy 34(1), 23-53.

Kumar, M. and Persaud, A., 2002. Pure contagion and investors' shifting risk appetite: analytical issues and empirical evidence. International Finance 5 (3), 401436.

Lane, P.R. (2011), Regional and global drivers of the portfolio holdings of Asian investors, in Devereux, M.B., Lane, P.R., Park, C.-Y. and S.-J. Wei (eds.), The Dynamics of Asian Financial Integration - Facts and Analytics”, 93-109, Routledge, Abingdon, UK.

Leduc, S. and Spiegel, M. M., 2013, Is Asia Decoupling from the United States (Again)? Pacific Economic Review, 18(3), 345-369.

Liu, L., 2013. International stock market interdependence: are developing markets the same as developed markets? Journal of International Financial Markets Inst. Money 26, 226-238.

Loh, L. 2013, Co-movement of Asia-Pacific with European and US stock market returns: A cross-time-frequency analysis, Research in International Business and Finance 29, 1- 13

Magud, N. and Reinhart, C. (2006). Capital controls: An evaluation. NBER Working Paper, 11973.

Narayan S., Sriananthakumar, S. and Islam, S. Z, 2014, Stock market integration of emerging Asian economies: Patterns and causes, Economic Modelling 39, 19-31

Park, C.-Y. (2013), “Asian capital market integration: theory and evidence”, Asian Development Bank Working Paper no. 351, Manila, Philippines.

Park, C. -Y. and Lee, J. -W. (2011). Financial integration in emerging Asia: Challenges and prospects. Asian Economic Policy Review 6, 176-198.

Phillips, P.C., D. Sul (2007), Transition Modeling and Econometric Convergence Tests, Econometrica, 75, 6, 1771-1855.

Rughoo A. and K. You (2016), Asian financial integration: Global or regional? Evidence from money and bond markets, International Review of Financial Analysis 48, 419-434.

Sharma, A. and Seth, N., 2012. Literature review of stock market integration: a global perspective. Qualitative Research in Financial Markets 4 (1), 84-122.

Tam, P.S., Tam, P.I. (2012), Rethinking stock market integration: Globalization, valuation and convergence, SFB 649 Discussion Paper 2012-052. 
Wang, L., 2014, Who moves East Asian stock markets? The role of the 2007-2009 global financial crisis, Journal of International Financial Markets, Institutions and Money 28, 182- 203.

Wang, Q., Zhu, Y., Yang, L., and Mul, R. A. H., 2017, Coupling detrended fluctuation analysis of Asian stock markets, Physica A 471, 337-350.

Wu, L., Meng, Q. and Xu, K., 2015, 'Slow-burn' spillover and 'fast and furious' contagion: a study of international stock markets, Quantitative Finance 15 (6), 933958. 
Table 1 logt convergence tests for the Asian countries

\begin{tabular}{|c|c|c|c|c|c|}
\hline \multirow[t]{2}{*}{ Aggregate/Sectors } & & \multicolumn{2}{|c|}{$\begin{array}{l}\text { Pre-crisis period } \\
\text { 2000M1-2007M9 }\end{array}$} & \multicolumn{2}{|c|}{$\begin{array}{l}\text { Post-crisis period } \\
\text { 2009M9-2016M9 }\end{array}$} \\
\hline & & $\hat{b}$ & t-stat & $\hat{b}$ & t-stat \\
\hline \multirow[t]{3}{*}{$\begin{array}{l}\text { Aggregate Stock } \\
\text { Market Indices }\end{array}$} & Relative to the US & $-0.526 *$ & -1.771 & 0.562 & 6.293 \\
\hline & Relative to Japan & $-0.501^{*}$ & -1.765 & 0.595 & 7.370 \\
\hline & Relative to Asia (ex Japan) & $-0.575^{*}$ & -1.883 & 0.528 & 5.609 \\
\hline \multirow[t]{3}{*}{ Consumer Goods } & Relative to the US & $-0.859 *$ & -5.379 & 0.869 & 9.825 \\
\hline & Relative to Japan & $-0.886 *$ & -5.918 & 0.911 & 11.398 \\
\hline & Relative to Asia (ex Japan) & $-0.860 *$ & -5.469 & 0.839 & 8.666 \\
\hline \multirow[t]{3}{*}{ Financials } & Relative to the US & $-0.574^{*}$ & -3.536 & $-0.121^{\mathrm{T}}$ & -1.119 \\
\hline & Relative to Japan & $-0.517^{*}$ & -4.476 & $-0.037^{\mathrm{T}}$ & -0.409 \\
\hline & Relative to Asia (ex Japan) & $-0.654 *$ & -3.602 & $-0.162^{\mathrm{T}}$ & -1.365 \\
\hline \multirow[t]{3}{*}{ Industrials } & Relative to the US & $-0.447 *$ & -1.680 & 0.117 & 1.247 \\
\hline & Relative to Japan & $-0.452 *$ & -1.747 & 0.141 & 1.462 \\
\hline & Relative to Asia (ex Japan) & $-0.514^{*}$ & -1.837 & 0.078 & 0.856 \\
\hline \multirow[t]{3}{*}{ Basic Materials } & Relative to the US & $-1.708 *$ & -9.945 & 1.051 & 6.021 \\
\hline & Relative to Japan & $-1.696 *$ & -10.813 & 1.068 & 6.680 \\
\hline & Relative to Asia (ex Japan) & $-1.807 *$ & -9.416 & 0.961 & 5.301 \\
\hline \multirow[t]{3}{*}{ Consumer Services } & Relative to the US & $-0.960 *$ & -4.337 & 1.350 & 4.691 \\
\hline & Relative to Japan & $-0.919 *$ & -4.297 & 1.365 & 4.520 \\
\hline & Relative to Asia (ex Japan) & $-0.991^{*}$ & -4.368 & 1.342 & 4.890 \\
\hline \multirow[t]{3}{*}{ Healthcare } & Relative to the US & $-1.357 *$ & -5.903 & 0.422 & 6.012 \\
\hline & Relative to Japan & $-1.378 *$ & -6.297 & 0.408 & 5.425 \\
\hline & Relative to Asia (ex Japan) & $-2.843 *$ & -13.941 & 0.385 & 5.076 \\
\hline \multirow[t]{3}{*}{ Oil and Gas } & Relative to the US & $-1.128 *$ & -4.400 & $-0.828 *$ & -11.300 \\
\hline & Relative to Japan & $-1.109 *$ & -4.342 & $-0.812^{*}$ & -14.599 \\
\hline & Relative to Asia (ex Japan) & $-0.496 *$ & -1.841 & $-0.788 *$ & -8.429 \\
\hline \multirow[t]{3}{*}{ Technology } & Relative to the US & $-1.096 *$ & -3.982 & $-0.393 *$ & -3.736 \\
\hline & Relative to Japan & $-1.053 *$ & -4.000 & $-0.348 *$ & -3.423 \\
\hline & Relative to Asia (ex Japan) & $-1.096 *$ & -4.162 & $-0.371^{*}$ & -3.632 \\
\hline \multirow[t]{3}{*}{ Telecommunication } & Relative to the US & $-0.510 *$ & -3.184 & $-0.123^{\mathrm{T}}$ & -0.785 \\
\hline & Relative to Japan & $-0.438 *$ & -2.832 & $-0.096^{\mathrm{T}}$ & -0.641 \\
\hline & Relative to Asia (ex Japan) & $-0.576^{*}$ & -3.326 & $-0.109^{\mathrm{T}}$ & -0.702 \\
\hline \multirow[t]{3}{*}{ Utility } & Relative to the US & $-0.905^{*}$ & -2.996 & 0.959 & 9.666 \\
\hline & Relative to Japan & $-0.832 *$ & -2.810 & 0.982 & 12.188 \\
\hline & Relative to Asia (ex Japan) & $-0.899 *$ & -2.875 & 0.946 & 9.487 \\
\hline
\end{tabular}

Note: * indicates rejection of the null hypothesis of convergence at the $5 \%$ significance level; ${ }^{\mathrm{T}}$ indicates transitional divergence and turn-around phase. For the Aggregate Stock Market Indices, Consumer Goods, Financial and Industrials Sectors, all 12 Asian economies are included. Due to data limitation, Singapore and Sri Lanka are not included for Basic Materials sector; Indonesia for Consumer for Services sector; Hong Kong, Malaysia, Taiwan, and Sri Lanka for Healthcare sector, Indonesia and Taiwan for Oil \& Gas sector; Indonesia, Malaysia, Philippines, Pakistan, and Sri Lanka for Technology sector, Taiwan and Sri Lanka for Telecommunication sector; Indonesia, Singapore, Taiwan and Sri Lanka for Utility sector. 
Table 2. Club convergence tests for the Oil \& Gas and Technology Sectors in post-crisis period (2009M9-2016M9)

\begin{tabular}{|c|c|c|}
\hline \multicolumn{3}{|c|}{ Oil \& Gas Sector } \\
\hline Relative to the US & Club 1 & \multirow{3}{*}{$\begin{array}{l}\text { China, India, Hong Kong, Malaysia, } \\
\text { Philippine, Thailand, Pakistan, Sri Lanka }\end{array}$} \\
\hline & $\widehat{b}: 0.410$ & \\
\hline & t-stat: 6.600 & \\
\hline & Divergent & \multirow[t]{3}{*}{ Singapore, South Korea } \\
\hline & $\widehat{b}:-4.667 *$ & \\
\hline & t-stat: -5.545 & \\
\hline \multirow[t]{4}{*}{ Relative to Japan } & Club 1 & \multirow{3}{*}{$\begin{array}{l}\text { China, India, Hong Kong, Malaysia, } \\
\text { Philippine, Thailand, South Korea, } \\
\text { Pakistan, Sri Lanka }\end{array}$} \\
\hline & $\widehat{b}: 0.005$ & \\
\hline & t-stat: 0.009 & \\
\hline & Divergent & Singapore \\
\hline \multirow[t]{4}{*}{ Relative to Asia (ex Japan) } & Club 1 & \multirow{3}{*}{$\begin{array}{l}\text { China, India, Hong Kong, Malaysia, } \\
\text { Philippine, Thailand, South Korea, } \\
\text { Pakistan, Sri Lanka }\end{array}$} \\
\hline & $\hat{b}: 0.009$ & \\
\hline & t-stat: 0.150 & \\
\hline & Divergent & Singapore \\
\hline \multicolumn{3}{|c|}{ Technology Sector } \\
\hline \multirow[t]{6}{*}{ Relative to the US } & Club 1 & \multirow[t]{3}{*}{ Hong Kong, Taiwan } \\
\hline & $\widehat{b}: 0.364$ & \\
\hline & t-stat: 1.868 & \\
\hline & Club 2 & \multirow{3}{*}{$\begin{array}{l}\text { China, India, Singapore, Thailand, South } \\
\text { Korea }\end{array}$} \\
\hline & $\widehat{b}: 0.529$ & \\
\hline & t-stat: 2.373 & \\
\hline \multirow[t]{6}{*}{ Relative to Japan } & Club 1 & \multirow[t]{3}{*}{ Hong Kong, Taiwan } \\
\hline & $\widehat{b}: 0.407$ & \\
\hline & t-stat: 2.026 & \\
\hline & Club 2 & \multirow{3}{*}{$\begin{array}{l}\text { China, India, Singapore, Thailand, South } \\
\text { Korea }\end{array}$} \\
\hline & $\hat{b}: 0.575$ & \\
\hline & t-stat: 2.675 & \\
\hline \multirow[t]{6}{*}{ Relative to Asia (ex Japan) } & Club 1 & \multirow[t]{3}{*}{ Hong Kong, Taiwan } \\
\hline & $\widehat{b}: 0.377$ & \\
\hline & t-stat: 1.876 & \\
\hline & Club 2 & \multirow{3}{*}{$\begin{array}{l}\text { China, India, Singapore, Thailand, South } \\
\text { Korea }\end{array}$} \\
\hline & $\widehat{b}: 0.553$ & \\
\hline & t-stat: 2.512 & \\
\hline
\end{tabular}

Note: * indicates rejection of the null hypothesis of convergence at the $5 \%$ significance level. 
Table 3. Club convergence tests for Aggregate Stock Market Indices in the precrisis period (2000M1-2007M9)

\begin{tabular}{|c|c|c|}
\hline \multicolumn{3}{|c|}{ Aggregate Stock Market Indices } \\
\hline \multirow[t]{6}{*}{ Relative to the US } & Club 1 & \multirow{3}{*}{$\begin{array}{l}\text { India, Hong Kong, Indonesia, Malaysia, } \\
\text { Philippine, Singapore, South Korea, } \\
\text { Taiwan, Pakistan, Sri Lanka }\end{array}$} \\
\hline & $\hat{b}: 0.785$ & \\
\hline & t-stat: 3.492 & \\
\hline & Club 2 & \multirow[t]{3}{*}{ China, Thailand } \\
\hline & $\hat{b}:-0.903^{\top}$ & \\
\hline & t-stat: -0.547 & \\
\hline \multirow[t]{6}{*}{ Relative to the Japan } & Club 1 & \multirow{3}{*}{$\begin{array}{l}\text { India, Hong Kong, Indonesia, Malaysia, } \\
\text { Philippine, Singapore, South Korea, } \\
\text { Taiwan, Pakistan, Sri Lanka }\end{array}$} \\
\hline & $\widehat{b}: 0.811$ & \\
\hline & t-stat: 3.970 & \\
\hline & Club 2 & \multirow[t]{3}{*}{ China, Thailand } \\
\hline & $\hat{b}:-0.882^{\top}$ & \\
\hline & t-stat: -0.546 & \\
\hline \multirow[t]{6}{*}{ Relative to Asia (ex Japan) } & Club 1 & \multirow{3}{*}{$\begin{array}{l}\text { India, Hong Kong, Indonesia, Malaysia, } \\
\text { Philippine, Singapore, South Korea, } \\
\text { Taiwan, Pakistan, Sri Lanka }\end{array}$} \\
\hline & $\hat{b}: 0.734$ & \\
\hline & t-stat: 3.095 & \\
\hline & Club 2 & \multirow[t]{3}{*}{ China, Thailand } \\
\hline & $\hat{b}:-0.953^{\top}$ & \\
\hline & t-stat: -0.589 & \\
\hline \multicolumn{3}{|c|}{ 1. Financials Sector } \\
\hline Relative to the US & Club 1 & \multirow{3}{*}{$\begin{array}{l}\text { China, India, Indonesia, Philippine, } \\
\text { Pakistan }\end{array}$} \\
\hline & $\hat{b}: 0.623$ & \\
\hline & t-stat: 5.449 & \\
\hline & Club 2 & \multirow[t]{3}{*}{ Hong Kong, Singapore, Sri Lanka } \\
\hline & $\hat{b}: 1.531$ & \\
\hline & t-stat: 2.959 & \\
\hline & Club 3 & \multirow[t]{3}{*}{ Malaysia, South Korea } \\
\hline & $\hat{b}:-2.569^{\top}$ & \\
\hline & t-stat -0.906 & \\
\hline & Club 4 & \multirow[t]{3}{*}{ Thailand, Taiwan } \\
\hline & $\hat{b}: 0.222$ & \\
\hline & t-stat: 9.218 & \\
\hline \multirow[t]{6}{*}{ Relative to Japan } & Club 1 & \multirow{3}{*}{$\begin{array}{l}\text { China, India, Indonesia, Philippine, South } \\
\text { Korea, Pakistan }\end{array}$} \\
\hline & $\hat{b}: 0.394$ & \\
\hline & t-stat: 3.947 & \\
\hline & Club 2 & \multirow{3}{*}{$\begin{array}{l}\text { Hong Kong, Malaysia, Singapore, Thailand, } \\
\text { Taiwan, Sri Lanka }\end{array}$} \\
\hline & $\hat{b}: 0.232$ & \\
\hline & t-stat: 1.576 & \\
\hline \multirow[t]{6}{*}{ Relative to Asia (ex Japan) } & Club 1 & \multirow{3}{*}{$\begin{array}{l}\text { China, India, Indonesia, Philippine, South } \\
\text { Korea, Pakistan }\end{array}$} \\
\hline & $\hat{b}: 0.260$ & \\
\hline & t-stat: 1.980 & \\
\hline & Club 2 & \multirow{3}{*}{$\begin{array}{l}\text { Hong Kong, Malaysia, Singapore, Thailand, } \\
\text { Taiwan, Sri Lanka }\end{array}$} \\
\hline & $\widehat{b}: 0.090$ & \\
\hline & t-stat: 0.542 & \\
\hline \multicolumn{3}{|c|}{ 2. Industrial Sector } \\
\hline
\end{tabular}




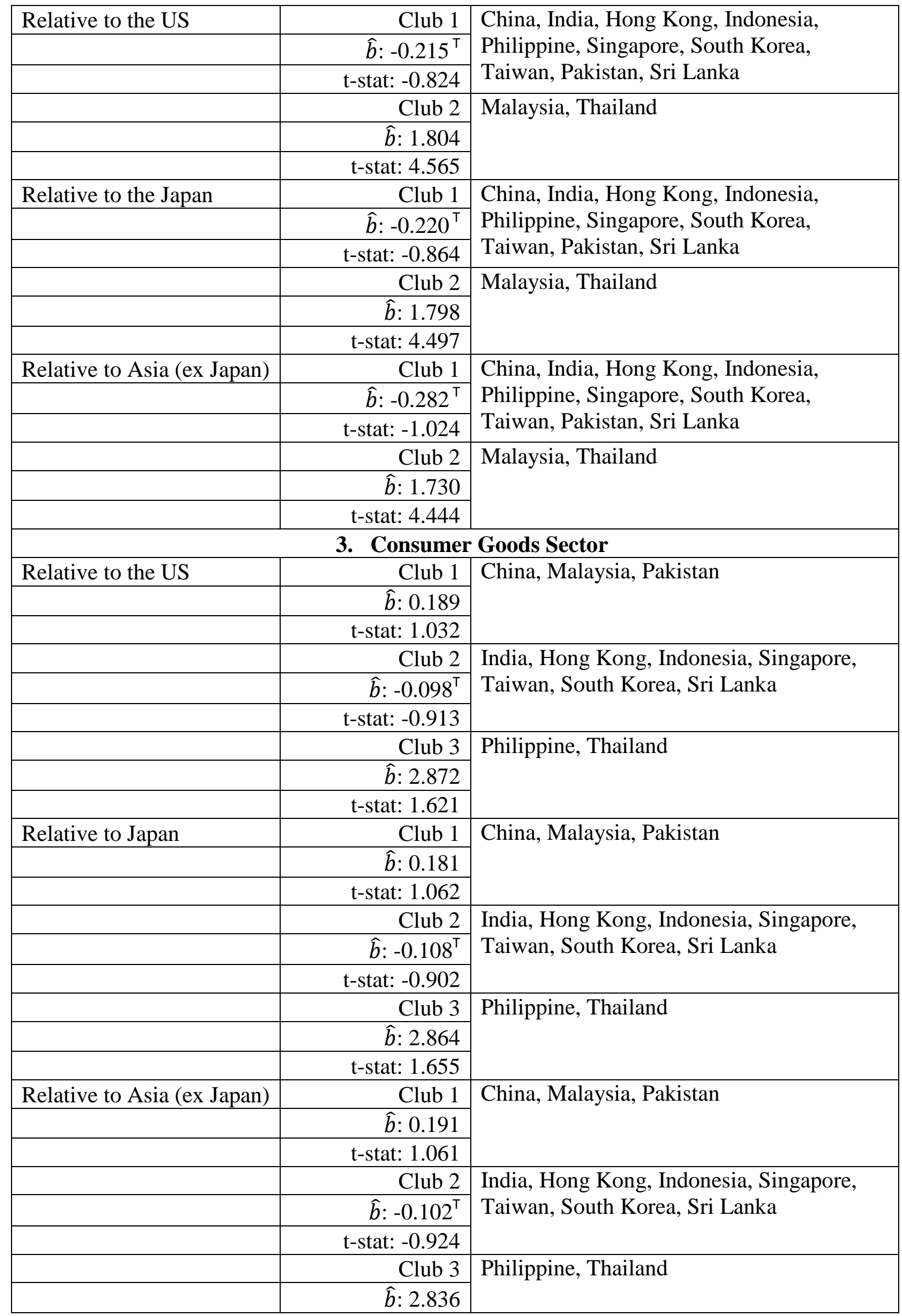




\begin{tabular}{|c|c|c|}
\hline & t-stat: 1.560 & \\
\hline \multicolumn{3}{|c|}{ 4. Consumer Services Sector } \\
\hline \multirow[t]{6}{*}{ Relative to the US } & Club 1 & \multirow{3}{*}{$\begin{array}{l}\text { India, Hong Kong, Malaysia, Philippine, } \\
\text { Singapore, Thailand, South Korea, Pakistan, } \\
\text { Sri Lanka }\end{array}$} \\
\hline & $\widehat{b}: 0.785$ & \\
\hline & t-stat: 3.492 & \\
\hline & Divergent & \multirow[t]{3}{*}{ China, Taiwan } \\
\hline & $\hat{b}:-4.803$ & \\
\hline & t-stat: $-6.053 *$ & \\
\hline \multirow[t]{6}{*}{ Relative to Japan } & Club 1 & \multirow{3}{*}{$\begin{array}{l}\text { India, Hong Kong, Malaysia, Philippine, } \\
\text { Singapore, Thailand, South Korea, Pakistan, } \\
\text { Sri Lanka }\end{array}$} \\
\hline & $\widehat{b}: 0.415$ & \\
\hline & t-stat: 1.842 & \\
\hline & Divergent & \multirow[t]{3}{*}{ China, Taiwan } \\
\hline & $\hat{b}:-4.770$ & \\
\hline & t-stat: $-5.859 *$ & \\
\hline \multirow[t]{6}{*}{ Relative to Asia (ex Japan) } & Club 1 & \multirow{3}{*}{$\begin{array}{l}\text { India, Hong Kong, Malaysia, Philippine, } \\
\text { Singapore, Thailand, South Korea, Pakistan, } \\
\text { Sri Lanka }\end{array}$} \\
\hline & $\hat{b}: 0.851$ & \\
\hline & t-stat: 3.093 & \\
\hline & Divergent & \multirow[t]{3}{*}{ China, Taiwan } \\
\hline & $\hat{b}:-1.665$ & \\
\hline & t-stat: $-4.006 *$ & \\
\hline \multicolumn{3}{|c|}{ 5. Oil \& Gas Sector } \\
\hline Relative to the US & Club 1 & \multirow[t]{3}{*}{ China, Hong Kong, Thailand, South Korea } \\
\hline & $\hat{b}:-0.009^{\top}$ & \\
\hline & t-stat: -0.070 & \\
\hline & Club 2 & \multirow[t]{3}{*}{ India, Malaysia, Philippine, Singapore } \\
\hline & $\hat{b}: 0.542$ & \\
\hline & t-stat: 4.220 & \\
\hline & Club 3 & \multirow[t]{3}{*}{ Pakistan, Sri Lanka } \\
\hline & $\widehat{b}:-2.090^{\top}$ & \\
\hline & t-stat: -1.075 & \\
\hline \multirow[t]{9}{*}{ Relative to Japan } & Club 1 & \multirow[t]{3}{*}{ China, Hong Kong, Thailand, South Korea } \\
\hline & $\hat{b}: 0.010$ & \\
\hline & t-stat: 0.083 & \\
\hline & Club 2 & \multirow[t]{3}{*}{ India, Malaysia, Philippine, Singapore } \\
\hline & $\hat{b}: 0.561$ & \\
\hline & t-stat: 4.380 & \\
\hline & Club 3 & \multirow[t]{3}{*}{ Pakistan, Sri Lanka } \\
\hline & $\widehat{b}:-2.071^{\top}$ & \\
\hline & t-stat: -1.055 & \\
\hline \multirow[t]{6}{*}{ Relative to Asia (ex Japan) } & Club 1 & \multirow[t]{3}{*}{ China, Hong Kong, Thailand, South Korea } \\
\hline & $\hat{b}: 1.125$ & \\
\hline & t-stat: 9.006 & \\
\hline & Club 2 & \multirow[t]{3}{*}{ India, Malaysia, Philippine, Singapore } \\
\hline & $\hat{b}: 0.609$ & \\
\hline & t-stat: 4.672 & \\
\hline
\end{tabular}




\begin{tabular}{|c|c|c|}
\hline & Club 3 & \multirow[t]{3}{*}{ Pakistan, Sri Lanka } \\
\hline & $\hat{b}:-2.028^{\top}$ & \\
\hline & t-stat: -1.046 & \\
\hline \multicolumn{3}{|c|}{ 6. Basic Materials Sector } \\
\hline Relative to the US & Club 1 & \multirow[t]{3}{*}{ China, Indonesia, South Korea } \\
\hline & $\hat{b}: 0.443$ & \\
\hline & t-stat: 3.589 & \\
\hline & Club 2 & \multirow[t]{3}{*}{ India, Hong Kong, Philippine } \\
\hline & $\hat{b}: 0.774$ & \\
\hline & t-stat: 5.158 & \\
\hline & Club 3 & \multirow[t]{3}{*}{ Malaysia, Thailand, Taiwan, Pakistan } \\
\hline & $\hat{b}: 0.603$ & \\
\hline & t-stat: 7.056 & \\
\hline Relative to Japan & Club 1 & \multirow[t]{3}{*}{ China, Indonesia, South Korea } \\
\hline & $\hat{b}: 0.453$ & \\
\hline & t-stat: 3.788 & \\
\hline & Club 2 & \multirow[t]{3}{*}{ India, Hong Kong, Philippine } \\
\hline & $\hat{b}: 0.785$ & \\
\hline & t-stat: 5.318 & \\
\hline & Club 3 & \multirow[t]{3}{*}{ Malaysia, Thailand, Taiwan, Pakistan } \\
\hline & $\hat{b}: 0.617$ & \\
\hline & t-stat: 8.900 & \\
\hline Relative to Asia (ex Japan) & Club 1 & \multirow[t]{3}{*}{ China, Indonesia, South Korea } \\
\hline & $\hat{b}: 0.352$ & \\
\hline & t-stat: 2.746 & \\
\hline & Club 2 & \multirow[t]{3}{*}{ India, Hong Kong, Philippine } \\
\hline & $\hat{b}: 0.677$ & \\
\hline & t-stat: 4.410 & \\
\hline & Club 3 & \multirow[t]{3}{*}{ Malaysia, Thailand, Taiwan, Pakistan } \\
\hline & $\hat{b}: 0.497$ & \\
\hline & t-stat: 4.560 & \\
\hline \multicolumn{3}{|c|}{ 7. Telecommunication Sector } \\
\hline Relative to the US & Club 1 & \multirow{3}{*}{$\begin{array}{l}\text { China, India, Hong Kong, Indonesia, } \\
\text { Philippine, Singapore, Pakistan }\end{array}$} \\
\hline & $\hat{b}: 0.067$ & \\
\hline & t-stat: 0.423 & \\
\hline & Club 2 & \multirow[t]{3}{*}{ Malaysia, Thailand, South Korea } \\
\hline & $\hat{b}: 1.273$ & \\
\hline & t-stat: 9.754 & \\
\hline Relative to Japan & Club 1 & \multirow{3}{*}{$\begin{array}{l}\text { China, India, Hong Kong, Indonesia, } \\
\text { Philippine, Singapore, Pakistan }\end{array}$} \\
\hline & $\hat{b}: 0.138$ & \\
\hline & t-stat: 0.897 & \\
\hline & Club 2 & \multirow[t]{3}{*}{ Malaysia, Thailand, South Korea } \\
\hline & $\hat{b}: 1.350$ & \\
\hline & t-stat: 10.323 & \\
\hline Relative to Asia (ex Japan) & Club 1 & \multirow{3}{*}{$\begin{array}{l}\text { China, India, Hong Kong, Indonesia, } \\
\text { Philippine }\end{array}$} \\
\hline & $\hat{b}: 0.557$ & \\
\hline & t-stat: 4.316 & \\
\hline
\end{tabular}




\begin{tabular}{|c|c|c|}
\hline & Club 2 & \multirow{3}{*}{$\begin{array}{l}\text { Malaysia, Singapore, Thailand, South } \\
\text { Korea, Pakistan }\end{array}$} \\
\hline & $\hat{b}: 0.929$ & \\
\hline & t-stat: 8.833 & \\
\hline \multicolumn{3}{|c|}{ 8. Healthcare Sector } \\
\hline Relative to the US & Club 1 & \multirow[t]{3}{*}{ Singapore, Thailand, South Korea, Pakistan } \\
\hline & $\hat{b}: 2.128$ & \\
\hline & t-stat: 4.803 & \\
\hline & Club 2 & \multirow[t]{3}{*}{ China, Indonesia } \\
\hline & $\hat{b}:-0.455^{\top}$ & \\
\hline & t-stat: -0.710 & \\
\hline & Divergent & \multirow[t]{3}{*}{ India, Philippine } \\
\hline & $\hat{b}:-4.700$ & \\
\hline & t-stat: $-5.001^{*}$ & \\
\hline Relative to Japan & Club 1 & \multirow[t]{3}{*}{ Singapore, Thailand, South Korea, Pakistan } \\
\hline & $\hat{b}: 2.108$ & \\
\hline & t-stat: 4.820 & \\
\hline & Club 2 & \multirow[t]{3}{*}{ China, Indonesia } \\
\hline & $\hat{b}:-0.478^{\top}$ & \\
\hline & t-stat: -0.737 & \\
\hline & Divergent & \multirow{3}{*}{ India, Philippine } \\
\hline & $\hat{b}:-4.710$ & \\
\hline & t-stat: $-4.977^{*}$ & \\
\hline Relative to Asia (ex Japan) & Club 1 & \multirow[t]{3}{*}{ Singapore, Thailand, South Korea, Pakistan } \\
\hline & $\hat{b}: 2.132$ & \\
\hline & t-stat: 4.772 & \\
\hline & Club 2 & \multirow{3}{*}{ China, Indonesia } \\
\hline & $\hat{b}:-0.447^{\top}$ & \\
\hline & t-stat: -0.688 & \\
\hline & Divergent & \multirow[t]{3}{*}{ India, Philippine } \\
\hline & $\hat{b}:-4.692$ & \\
\hline & t-stat: $-4.948^{*}$ & \\
\hline \multicolumn{3}{|c|}{ 9. Utility Sector } \\
\hline Relative to the US & Club 1 & \multirow[t]{3}{*}{ China, India, Philippine } \\
\hline & $\hat{b}: 0.520$ & \\
\hline & t-stat: 3.271 & \\
\hline & Club 2 & \multirow{3}{*}{$\begin{array}{l}\text { Hong Kong, Malaysia, Thailand, South } \\
\text { Korea, Pakistan }\end{array}$} \\
\hline & $\hat{b}: 1.393$ & \\
\hline & t-stat: 3.598 & \\
\hline Relative to Japan & Club 1 & \multirow[t]{3}{*}{ China, India, Philippine } \\
\hline & $\hat{b}: 0.592$ & \\
\hline & t-stat: 1.464 & \\
\hline & Club 2 & \multirow{3}{*}{$\begin{array}{l}\text { Hong Kong, Malaysia, Thailand, South } \\
\text { Korea, Pakistan }\end{array}$} \\
\hline & $\hat{b}: 1.393$ & \\
\hline & t-stat: 3.598 & \\
\hline Relative to Asia (ex Japan) & Club 1 & \multirow{2}{*}{ China, India, Philippine } \\
\hline & $\hat{b}: 0.530$ & \\
\hline
\end{tabular}




\begin{tabular}{|c|c|c|}
\hline & t-stat: 3.295 & \\
\hline & Club 2 & \multirow{3}{*}{$\begin{array}{l}\text { Hong Kong, Malaysia, Thailand, South } \\
\text { Korea, Pakistan }\end{array}$} \\
\hline & $\hat{b}: 1.395$ & \\
\hline & t-stat: 3.513 & \\
\hline \multicolumn{3}{|c|}{ 10. Technology Sector } \\
\hline Relative to the US & Club 1 & \multirow{3}{*}{$\begin{array}{l}\text { India, Hong Kong, Singapore, Thailand, } \\
\text { Taiwan, South Korea }\end{array}$} \\
\hline & $\hat{b}:-0.066^{\top}$ & \\
\hline & t-stat: -0.939 & \\
\hline & Divergent & China \\
\hline Relative to Japan & Club 1 & \multirow{3}{*}{$\begin{array}{l}\text { India, Hong Kong, Singapore, Thailand, } \\
\text { Taiwan, South Korea }\end{array}$} \\
\hline & $\hat{b}:-0.033^{\top}$ & \\
\hline & t-stat: -0.684 & \\
\hline & Divergent & China \\
\hline Relative to Asia (ex Japan) & Club 1 & \multirow{3}{*}{$\begin{array}{l}\text { India, Hong Kong, Singapore, Thailand, } \\
\text { Taiwan, South Korea }\end{array}$} \\
\hline & $\hat{b}:-0.065^{\top}$ & \\
\hline & t-stat: -1.198 & \\
\hline & Divergent & China \\
\hline
\end{tabular}

Note: $*$ indicates rejection of the null hypothesis of convergence at the 5\% significance level; ${ }^{\mathrm{T}}$ indicates transitional divergence and turn around phase. 
Figure 1. Relative Transition Parameters for the Oil \& Gas Sector in the postcrisis period 2009M9-2016M9: Return differentials vis-à-vis the US

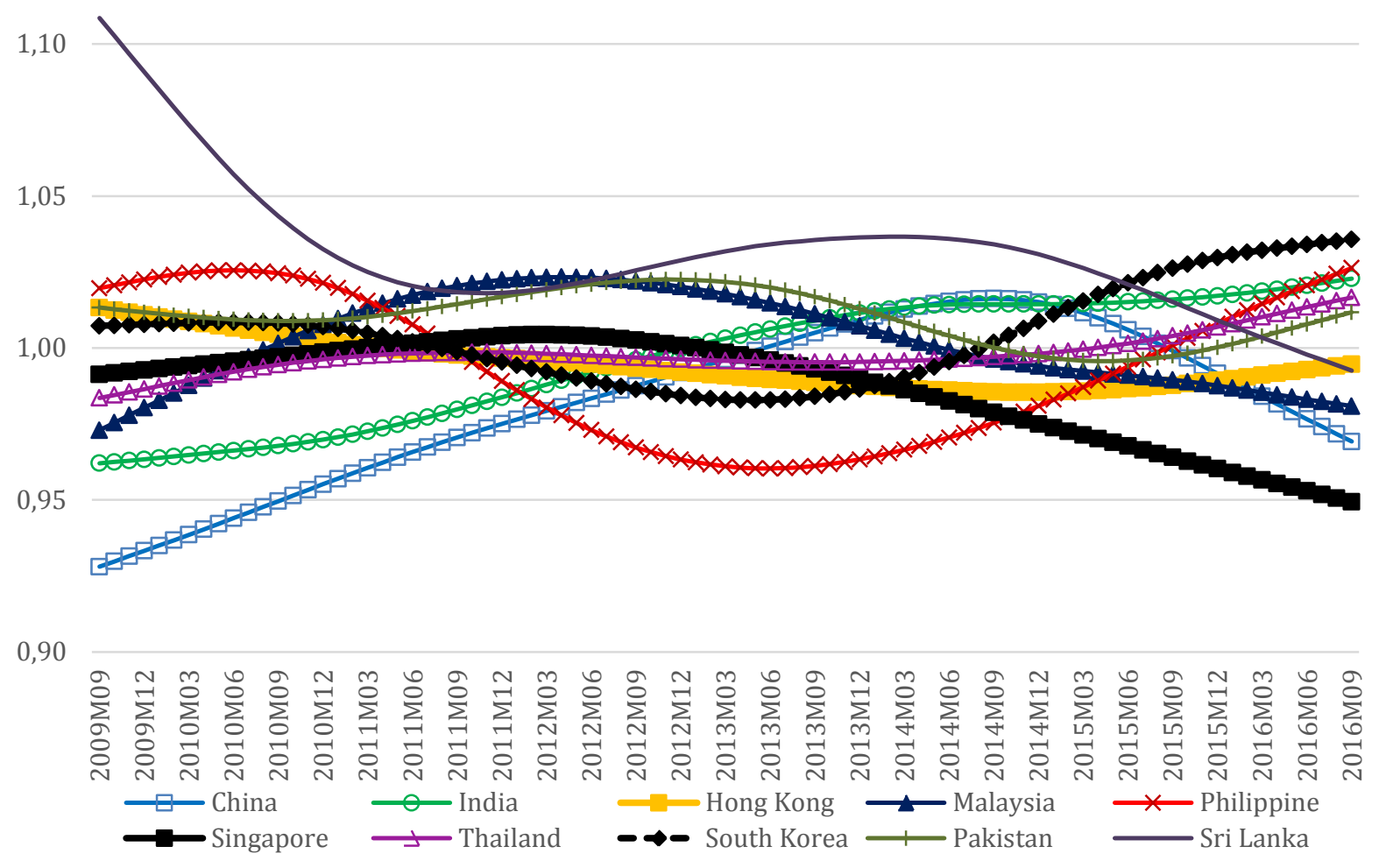

Figure 2. Relative Transition Parameters for the Oil \& Gas Sector in the postcrisis period 2009M9-2016M9: Return differentials vis-à-vis Japan

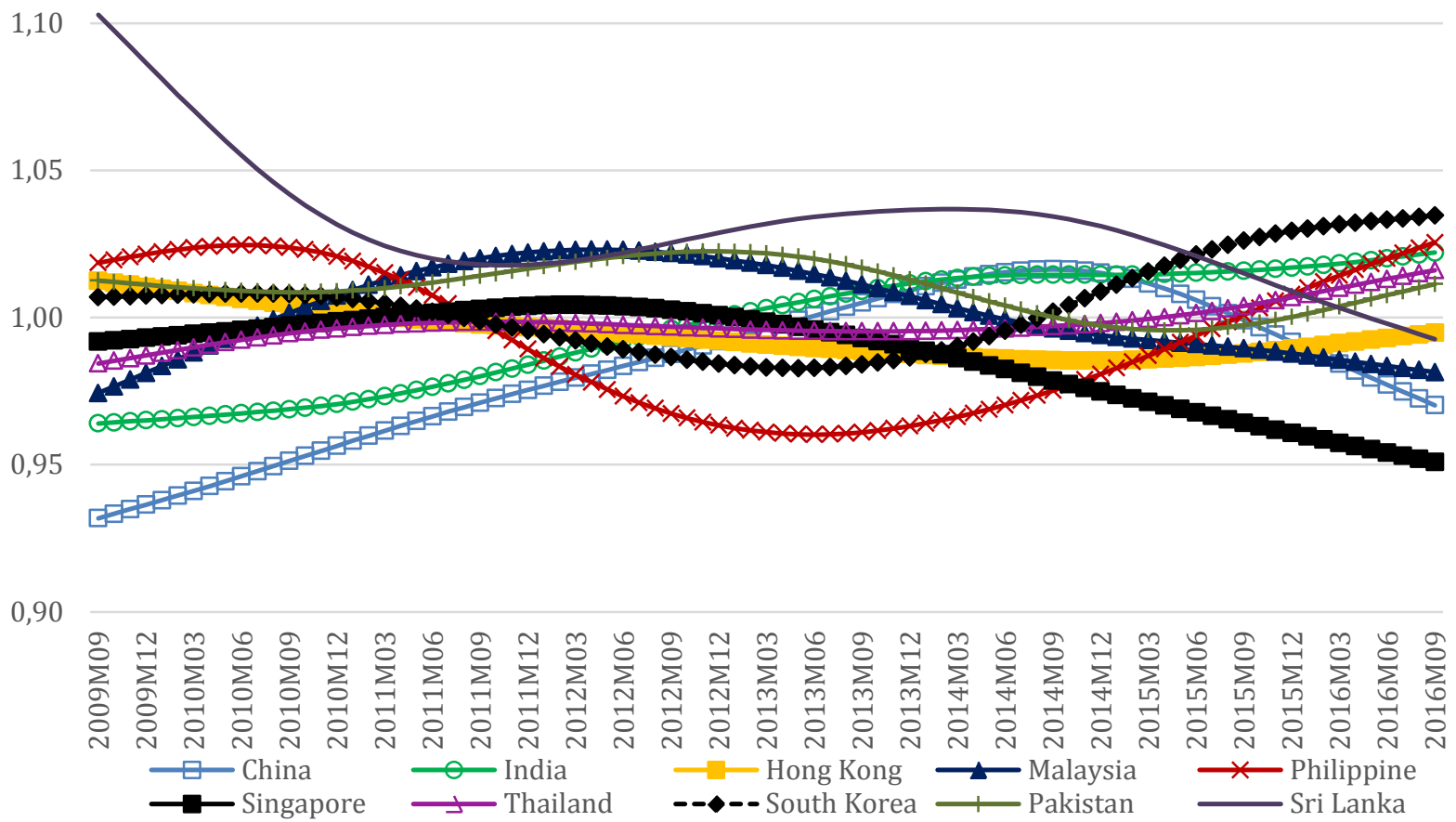


Figure 3. Relative Transition Parameters for the Oil \& Gas Sector in the postcrisis period 2009M9-2016M9: Return differentials vis-à-vis Asia (excluding Japan)

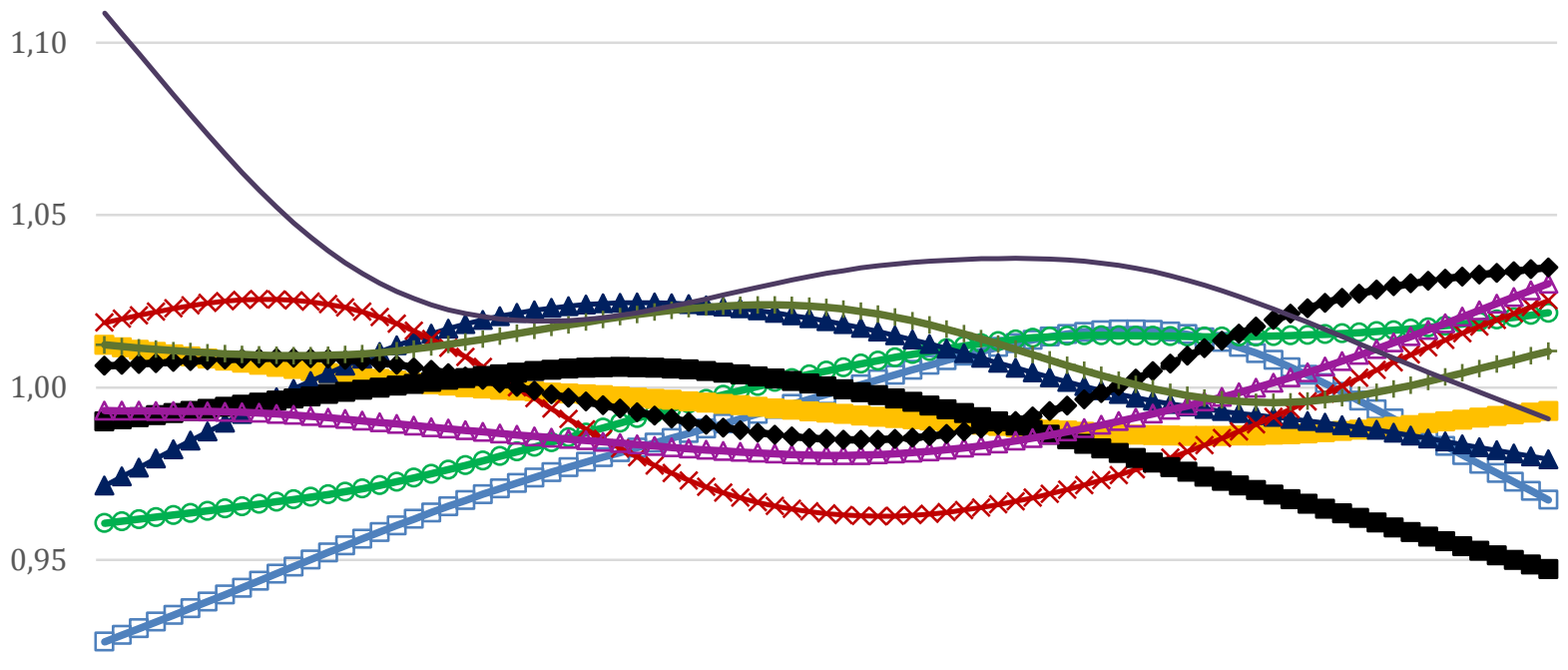

0,90

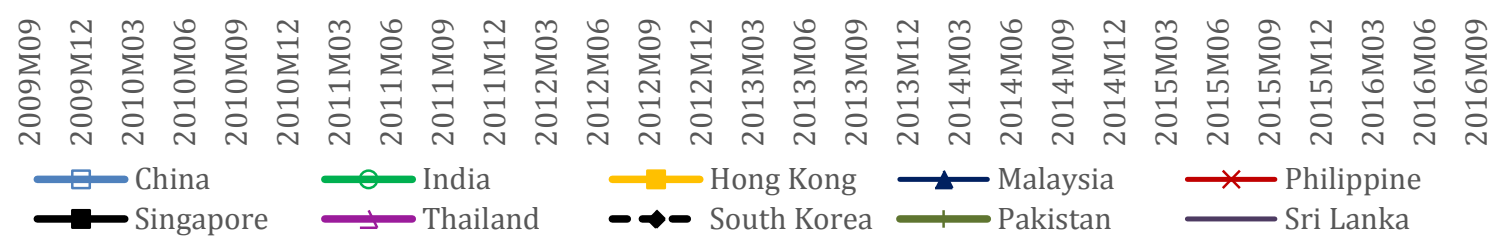

Figure 4. Relative Transition Parameters for the Technology Sector in the postcrisis period 2009M9-2016M9: Return differentials vis-à-vis the US

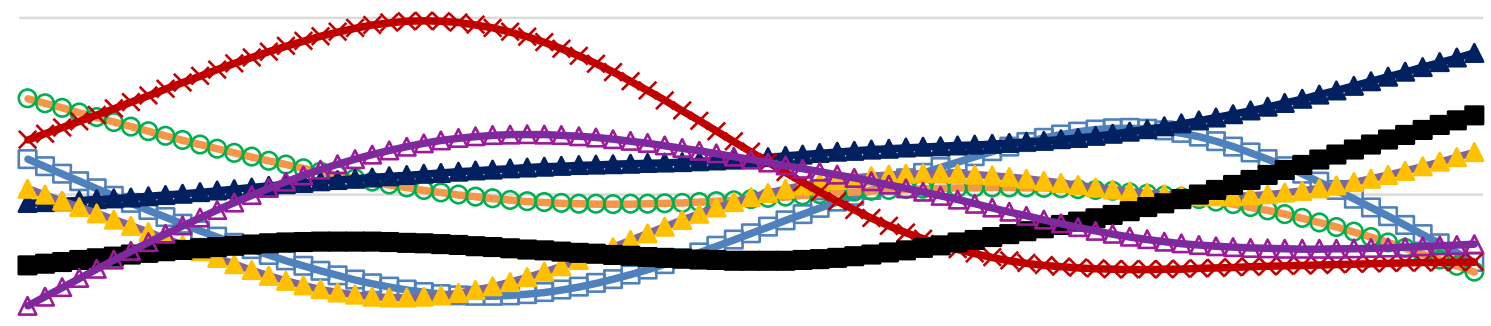

0,95

0,90

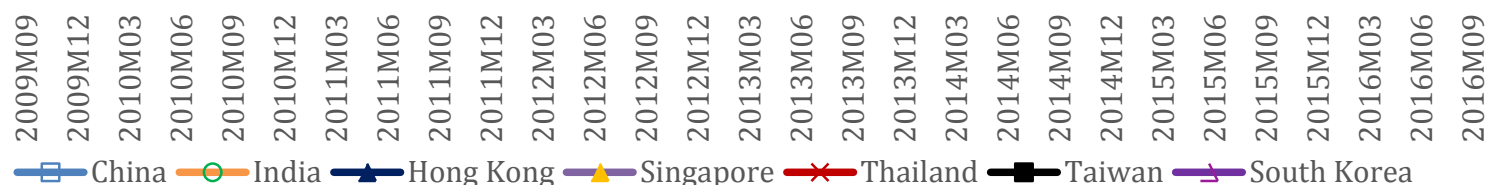


Figure 5. Relative Transition Parameters for the Technology Sector in the postcrisis period 2009M9-2016M9: Return differentials vis-à-vis Japan

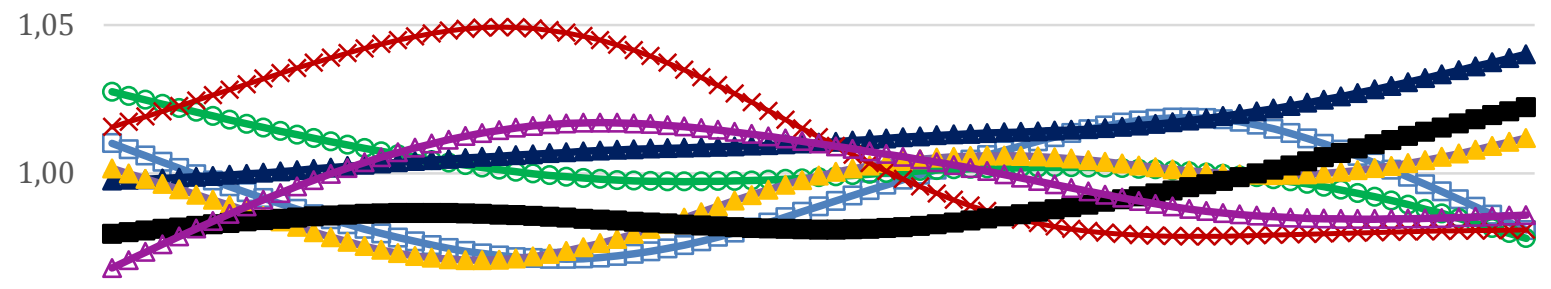

Figure 6. Relative Transition Parameters for the Technology Sector in the postcrisis period 2009M9-2016M9: Return differentials vis-à-vis Asia (excluding Japan)

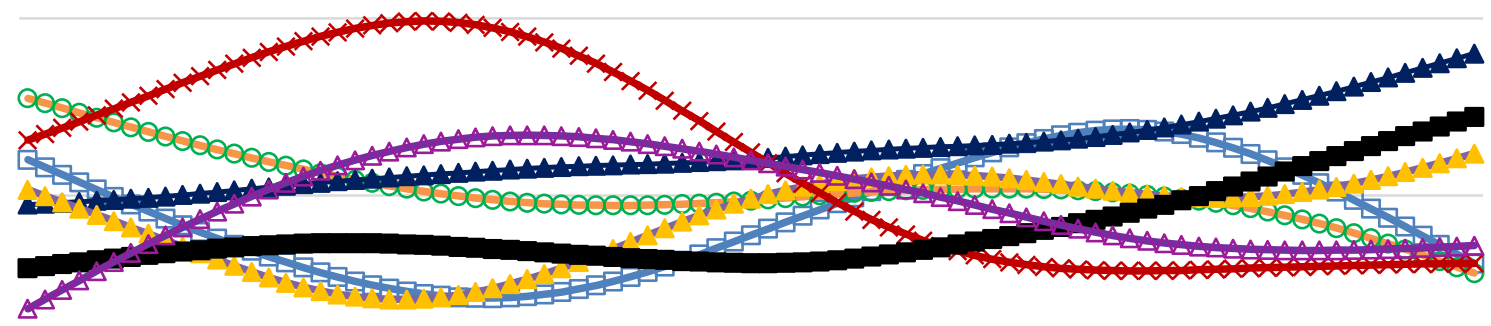

0,95 